\title{
Information gaps in the market for social services: retirement homes in the Czech Republic
}

\author{
Iveta Vrabková, Izabela Ertingerová, Roman Vavrek ${ }^{1}$
}

\begin{abstract}
The research address a partial issue of market failure in the form of information asymmetry. Within the public sector, social services, together with health services, belong to typical sectors where the information superiority of supply against demand is detected. The presence of asymmetrical/imperfect information within the social care has a significant effect on retired people who demand the services of retirement homes, and this effect occurs before as well as during the consumption of this service. The paper aims to identify and evaluate the information gaps of 159 official websites of retirement homes in the Czech Republic that are related to the supply of offered services. The evaluated websites of the retirement homes were selected in a way including all three types of the legal form of retirement homes (semi-budgetary units of regions, limited liability companies, church legal entities) that are present in this category of social services in the Czech Republic. The multi-criteria evaluation, performed by using the TOPSIS method, included 14 types of information (criteria). The TOPSIS method is based on the selection of the variant that is the closest one to the ideal variant and that is characterized by a vector. The results show that retirement homes insufficiently disclose several types of information. These include the conditions of acceptance into the retirement home, annual reports, some types of contact information, internal rules of the home, and the electronic link for the communication with the retirement home. In relation to the evaluation of the total level of 14 types of information being disclosed on the websites of retirement homes, it was revealed that $3 \%$ of them achieve an excellent level, $30 \%$ achieve a lesser than excellent level, $60 \%$ achieve a low level, and $7 \%$ of retirement homes achieve a very low level.
\end{abstract}

Keywords: information asymmetry, multi-criteria evaluation, social service, TOPSIS method, websites of retirement homes

JEL Classification: H41, D82, L33

Received: 16 May 2019 / Accepted: 2 July 2019 / Sent for Publication: 9 September 2019

\footnotetext{
${ }^{1}$ VŠB-TU of Ostrava, Faculty of Economics, Department of Public Economics, Czech republic iveta.vrabkova@vsb.cz; izabela.ertingerova@vsb.cz; roman.vavrek@vsb.cz

@ 2019 by the authors; licensee Review of Economic Perspectives / Národohospodárský obzor, Masaryk University, Faculty of Economics and Administration, Brno, Czech Republic. This article is an open access article distributed under the terms and conditions of the Creative Commons Attribution 3.0 license, Attribution - Non Commercial - No Derivatives.
} 


\section{Introduction}

The information gaps in the market for social services are a consequence of the information asymmetry that represents the information superiority of one side of a market transaction, (Boyer et al., 2003; Varian, 2014). The information superiority of the supply can generate the so-called imperfect information that the sellers disclose to the buyers before the transaction and that is related to attributes and functionality of the object of the transaction (for example, the social service). During this, the imperfect information can cause market deformations that are followed by phenomena such as negative selection, limited rationality, and moral hazard, (Sojka, 2002; Jurečka et al., 2018).

Social care, just like the health care, represents a typical example where arising from the nature of these services, the providers have considerable, expertly determined information superiority against the clients of these services. (Barile at al., 2014) The presence of asymmetrical information within the social care and health care has a significant impact on retired people who demand the services of retirement homes, and this impact occurs before as well as during the consumption of this service. The majority of authors researching the issue of social services (Netten and Davies, 1990; Průša, 2007; Mertl, 2008; Huang, Ku, 2011; Seifert, Schelling, 2018) are inclined to think that retired people, from the perspective of independent decision-making, represent a disadvantaged (endangered) segment of clients of social services, and during the decision-making on the selection of a retirement home, they often rely on the judgement and recommendations of others, in an ideal case, of current clients of social services or members of their own family.

Providing information about the content and quality of the supply of social services before consuming them is irreplaceable also because (a) social services are the socalled experience goods; (b) a large number of retired people do not have the knowledge and possibilities needed for acquiring information that would make the selection of the right choice easier. Holasová and Malík (2014) states that the providers of social services should, therefore, try to materialize the process of services, for example, via a description of the procedure of the social help, which would eliminate the ignorance of the clients. This especially applies to the cases when the demand for social service is related to existential issues connected to life, health, and rights, or substantial economic issues.

The informal social care on the level of households is being transferred to formalized (institutionalized) markets if the ability of informal care within the area of nutrition and personal care decreases to a threshold level. A typical example is represented by retirement homes that substitute personal care and also provide a home. (Netten and Davies, 1990; Průša, 2007; Mertl, 2008; Huang, Ku, 2011)

Within the field of residential social services for retired people in the Czech Republic, as a consequence of numerous socio-economic and demographic trends, there has been a long-term excess of demand over supply, which emphasises the topicality of the issue of information asymmetry in the context of quality of services being provided. According to official statistics of the Czech Social Security Administration, there were 2,410,000 old-age pensioners and 421,000 disability pensioners in the Czech Republic to the date of 31 December 2018. At the same time, there were 61,013 unsat- 
isfied applications recorded in which retired people were applying for being placed in a retirement home. The average time of waiting for acceptance into a retirement home in the Czech Republic is very long, being counted in years if it is a case of retired people with a lower degree of dependence on other person or with ability to use the social service in other forms (ambulatory, in the field). Shorter waiting time for the acceptance into a retirement home, counted in months, is recorded for the placement in a retirement home if it is a case of retired people with a high degree of dependence on the care. (Czech Social Security Administration, 2018) There is a remaining question whether the state of the unsatisfied demand for the social care of retirement homes has a negative impact on the quality of information about the services being offered by retirement homes that are disclosed online.

This paper aims to identify and evaluate the information gaps of 159 official websites of retirement homes in the Czech Republic that are related to the supply of the services being provided.

Concerning the defined aim, three research questions will be tested: RQ1: "Do retirement homes disclose basic and practical online information for future clients?"; RQ2: "Is it possible to determine the differences in quality of the disclosed online information of retirement homes with regard to the type of provider?"; RQ3: "Which important piece of information about the service being offered by the retirement home is not sufficiently disclosed?".

Identification and evaluation of information gaps are performed according to the multi-criteria method TOPSIS. It includes 159 retirement homes established by three types of providers (semi-budgetary units of regions, private limited liability companies, church legal entities), and during the selection of types of information, it takes into account the requirements of the Act no. 108/2006 Coll. on Social Services.

\section{Literature review}

The specifics of the issues of information asymmetry in the public sector, or the markets for health care, were recognized for the first time in the works done by K. J. Arrow in 1963. Arrow (1963) pointed to information asymmetry occurring in the markets for health care, caused by an extremely high degree of uncertainty. The conditions of uncertainty cause that (i.) patients often irrationally and not always correctly evaluate the quality of the health care provided for them; (ii.) accurate information is becoming very valuable goods; (iii.) information about the prediction of consequences of a treatment is intangible and it is limitedly tradeable on the side of supply as well as demand. (Frank, Salkever, 1994; Haas-Wilson, 2001; Robinson, 2001; Bloom et al., 2008)

According to Schaad (1998), the field of social services indisputably represents a typical example of a market where there is information asymmetry between the two participants of a contractual relationship. For the sector of social services, it is typical that the demand is not constant, but, on the contrary, it is irregular and unpredictable. Holasová (2014) states that the person interested in social service, due to a lack of knowledge and experience, is not able to accurately evaluate his/her health condition or the social issue emerged and the way how to solve it. McCaughey and Bruning 
(2010) state that in some cases, there can be situations when the persons interested in the service are limited in their abilities to look for all the information needed about the social service, and this is caused by the emerged burdensome social condition or a serious health condition. In this case, they satisfy their urgent needs by the selection of the first variant that fully or at least partially meets the minimal criteria for the solving of the current matter, opposed to keep looking for the optimal variant.

The persons interested in social service, based on the information available for the decision-making, can tend to choose such a provider of the social service who, in their opinion, seems to be the best one, and who is able to sufficiently satisfy their needs. Nevertheless, during the consumption of social service, it can be revealed that their choice was not right. Therefore, they are forced to look for all the information available again and re-evaluate it to make a different, better decision. This is linked to considerable costs of information needed by the client to be able to switch the service's provider but also to the switching costs, which mainly lie in the necessity of getting used to a different provider, often in a very short time. (Janíčko and Koubek, 2012)

In the Czech Republic, there is a predominance of institutionalized care for retired people, being provided by public entities. According to Kubalčíková and Havlíková (2016), liberalization and substitution of residential care by alternative forms of allday care are delayed by 20 years when compared with western Europe. The results of the study done by the aforementioned authors also show that home services (in-thefield social care) in the Czech Republic were not able to adapt to growing needs for the care for elderly adults, and the rising demand caused an unintended effect. Unregistered, profit-making caring homes emerged, which offer care of low quality and which provide poor working conditions for their employees. Health, as well as lives, of elderly adults, can be in danger if they choose such services.

The topic of insufficient supply of retirement homes is the issue in the majority of developed countries. Vlachantoni (2019) studies the impact of social policies, family background, and the health and social-economic status of the retired people on the demand for social care. The unsatisfied demand in the UK is connected to social services that are being provided simultaneously with residential services (for example, retirement homes) and that are focused on the tasks of everyday life, personal hygiene, and eating of the clients. Roblin et al. (2019) study the growing unsatisfied demand for residential social care and compare this care with retirement homes in the area of Ontario, through the prism of public funds. The growing demand causes long waiting times for placing into government-subsidized facilities with intensive social-health care. This leads to the decreasing of the equality within the access to residential care for retired people.

According to Průša and Horecký (2012), the information about social services should be easily accessible for everyone who could need it. The information accessibility and impartial counselling on the types and range of services available and on their providers should be accessible to the persons interested in the service not only in the social facilities but also, for example, on their websites. With the development of online social services, the websites now provide more information for the public. These types of information can reflect the quality of results of social facilities and their providing, 
with the objective to facilitate the selection of the concrete provider for the persons interested in the service.

\section{Methodology and data}

In the Czech Republic, according to the Register of social services providers, there are 529 organizations providing residential social services for the retired people, with a total capacity above 38 thousand places. Within this number, there are 349 semibudgetary units of regions, 67 church organizations, and 113 private providers of social services, among which there are 52 organizations with the legal form of a limited liability company. In connection with the Act on Social Services, since 1 January 2007, there are the rules effective for all the providers of social services - Standards for social services - that besides other things impose an obligation on them to disclose the information on the services provided, (Ministry of Labour and Social Affairs, 2019)

For the needs of identification and evaluation of the information gaps within the online sources, 159 websites (online sources) of retirement homes were analysed. The websites of retirement homes for the evaluation were selected so that they included all three types of legal form that are present in the Czech Republic in this category of social services. The number of retirement homes selected was determined with regard to mutually comparable frequency of all types of legal form.

\section{The selected retirement homes}

The legal form and the numbers of retirement homes for which the information disclosed on official websites were evaluated:

- semi-budgetary units of regions with the number of 52 such organizations (denoted as type A), representing $15 \%$ within the total number of all retirement homes of this type of legal form operating in the Czech Republic to the date of 1 January 2019 (randomly selected with regard to localization of retirement homes with the legal form of Ltd companies);

- $\quad$ private organizations (Ltd companies) with the number of 52 such organizations (denoted as type B), representing $100 \%$ within the total number of all retirement homes of this type of legal form operating in the Czech Republic to the date of 1 January 2019;

- $\quad$ church organizations with the number of 55 such organizations (denoted as type C), representing $82 \%$ within the total number of all retirement homes of this type of legal form operating in the Czech Republic to the date of 1 January 2019.

\section{The types of information evaluated}

Based on a review of expert literature sources, consultations with experts in the field of social work and services, and the requirements of the Act on Social Services, 14 types of information were determined as the criteria listed in Table 1 (criteria I1 - I14). These consist of two characteristic sets of information: (1) I1 - I7 represent basic and practical information, which is the obligatory information that the providers of social services are obliged to disclose by the Act on Social Services; (2) I8 - I14 represent contact and additional information, which presents the basic and practical information in a visual form, improving the transparency of social services (retirement homes). 
An important step within the whole calculation using the TOPSIS method is the determination of weight for the criteria. Keršuiene et al. (2010) divide the approaches for weight determination into four groups: subjective, expert, objective, and integrated (as a combination of the first and the second group of approaches).

The weight for the criteria was assigned in an integrated way, based on the consultations with experts on social services and the preferences of potential clients (see Table 1). The information was searched for on the websites of retirement homes during January and February 2019. The accessibility of a piece information was evaluated using a scale of $0-10$, where 0 points $=$ absence of the piece of information, and 10 points $=$ fully and easily accessible piece of information.

Table 1. Characteristics and weight of the pieces of information (criteria) evaluated for the retirement homes

\begin{tabular}{|c|c|c|}
\hline Code & criterion's description & weight \\
\hline I1 & type of social services of the retirement home & 7 \\
\hline $\mathrm{I} 2$ & characteristics of the retirement home's services & 7 \\
\hline I3 & retirement home's mission & 7 \\
\hline $\mathrm{I} 4$ & criteria for the acceptance into the retirement home & 9 \\
\hline I5 & $\begin{array}{l}\text { price list of the services (accommodation, eating, caring services) of the } \\
\text { retirement home }\end{array}$ & 9 \\
\hline I6 & information on the capacity of the retirement home & 7 \\
\hline I7 & annual reports of the retirement home & 5 \\
\hline I8 & $\begin{array}{l}\text { basic contact information of the retirement home (address, phone number, e- } \\
\text { mail) }\end{array}$ & 8 \\
\hline I9 & $\begin{array}{l}\text { localization contact information of the retirement home (map, transport } \\
\text { connection) }\end{array}$ & 8 \\
\hline I10 & $\begin{array}{l}\text { visualization of the retirement home (for example, images of the interior, } \\
\text { exterior, virtual presentation) }\end{array}$ & 8 \\
\hline I11 & activities in the retirement home (leisure time activities) & 8 \\
\hline $\mathrm{I} 12$ & downloadable application form into the retirement home & 7 \\
\hline $\mathrm{I} 13$ & $\begin{array}{l}\text { internal rules of the home (rights and responsibilities of the clients, visitors, } \\
\text { family members) }\end{array}$ & 6 \\
\hline I14 & electronic link for the communication with the retirement home & 6 \\
\hline
\end{tabular}

\section{The TOPSIS method}

The TOPSIS method (Technique for Order of Preference by Similarity to Ideal Solution) is a specific technique, representing one of the most frequently used MCDM methods (Multi-Criteria Decision Making), whose origin is attributed to authors Hwang, Yoon (1981), Yoon (1980), who developed the TOPSIS technique as an alternative to the ELECTRE method (Zavadskas et al. 2014). The TOPSIS method is based on the selection of the variant that is the closest one to the so-called ideal variant (characterized by the vector of the best criterial values) and at the same time the furthest one from the so-called basal variant (characterized by the vector of the worst criterial values). The TOPSIS method is being applied to solve decision-making tasks in the public as well as in the private sector, (Jablonský and Dlouhý, 2015; Ardielli and Bečica, 2018). 
The result of the TOPSIS technique is described by Streimikine et al. (2012) as the solution with the shortest distance to the positive ideal solution (PIS), calculated using the Euclid distance. The TOPSIS technique offers a solution that is the closest one to the above-mentioned PIS under given conditions, and that is the furthest one from the negative ideal solution (NIS), (Olson 2004; Zavadskas et al., 2016).

The procedure of the TOPSIS technique can be described in several steps:

1) putting the alternatives in order according to the corresponding, beforehand identified, criteria are captured by the $D$ matrix,

$$
D=\left(\begin{array}{ccccc} 
& X_{1} & X_{2} \ldots & X_{j} \ldots & X_{n} \\
A_{1} & x_{11} & x_{12} \ldots & x_{1 j} \ldots & x_{1 n} \\
A_{2} & x_{21} & x_{22} \ldots & x_{2 j} \ldots & x_{2 n} \\
: & : & : & : & : \\
A_{i} & x_{i 1} & x_{i 2} \ldots & x_{i j} \ldots & x_{i n} \\
: & : & : & : & : \\
A_{m} & x_{m 1} & x_{m 2} \ldots & x_{m j} \ldots & x_{m n}
\end{array}\right)
$$

where $A_{i}=i$ alternative, $x_{i j}=$ value of the $j$ criterion, reached by the $i$ alternative;

2) normalization of the created matrix according to formula (1):

$r_{i j}=x_{i j} / \sqrt{\sum_{j=1}^{j} x_{i j}^{2}}$

where $x_{i j}=$ value of the $j$ criterion reached by the $i$ alternative;

3) multiplication by the weight for the individual criteria according to formula (2):

$v_{i j}=w_{i j} \cdot r_{i j}$

where $v_{i j}=$ weighted normalized value, and $w_{i j}=$ criterion's weight;

4) identification of the PIS and NIS alternative according to formula (3):

$H_{j}=\max \left(w_{i j}\right), D_{j}=\min \left(w_{i j}\right)$

5) calculation of the distance from the PIS and NIS alternative according to formula (4):

$d_{i}^{+}=\left[\sum_{j=1}^{k}\left(w_{i j}-H_{j}\right)^{2},\right]^{1 / 2}, d_{i}^{-}=\left[\sum_{j=1}^{k}\left(w_{i j}-D_{j}\right)^{2},\right]^{1 / 2}$

6) calculation of the relative distance from the PIS alternative according to formula (5): 


$$
c_{i}=\frac{d_{i}^{-}}{d_{i}^{-}+d_{i}^{+}}
$$

where $c_{i}=$ relative closeness to PIS;

7) values $c_{i}$ lie in the interval $\langle 0,1\rangle$, where the basal variant has the value 0 , and the ideal variant has the value 1 . Putting the variants in order according to $c_{i}$ from the highest one to the lowest one. According to the required number of variants, those with the highest values of the indicator are selected. (Jablonský, Dlouhý, 2015; Vavrek, 2015)

\section{Empirical results}

The results of the multi-criteria evaluation using the TOPSIS method are determined (a) partially according to individual types of retirement homes A-C, and (b) in total for all retirement homes with the number of 159 retirement homes, regardless of their type.

Information gaps are detected according to the range of individual types of pieces of information from the perspective of two above-mentioned information areas. The total level of the information being provided is evaluated according to the determined fourlevel scale for the $c_{i}$ value:

- $\quad 1.00-0.80$ very high level of the information being disclosed;

- $\quad 0.79-0.60$ lesser than the very high level of the information being disclosed;

- $0.59-0.40$ low level of the information being disclosed;

- $0.39-0.10$ very low level of the information being disclosed.

Results for the type A retirement homes: semi-budgetary units of regions

The evaluation of the accessibility of online information I1 - I14 being disclosed by the type A retirement homes is strongly heterogenous (Fig. 1.). Based on the performed analysis of the range of individual 14 types of information within the conditions of 52 type A retirement homes, it can be stated that two specific information gaps were detected, and these gaps are related to:

- I4 criteria for the acceptance into the retirement home,

- $\quad$ I14 electronic link for the communication with the retirement home.

The values reached by $c_{i}$ cannot be described by normal distribution $(\mathrm{w}=0.949 ; \mathrm{p}=$ 0.044 ), as it is indicated by the graphical difference in the mean values (Fig. 1). The level of kurtosis $(\gamma=0.729)$, together with higher variability $(\mathrm{v}=18.16 \%)$, indicate higher differences in the evaluation of individual entities that manifest in the range being at the level of 0.487 of the relative distance to the PIS (Fig. 1). The mean value of the $c_{i}$ is 0.61 ; the minimum value of the $c_{i}$ is 0.43 ; and the maximal value of the $c_{i}$ is 0.92 .

Figure 1. Type A retirement homes: the range of the criteria and the $c_{i}$ values 


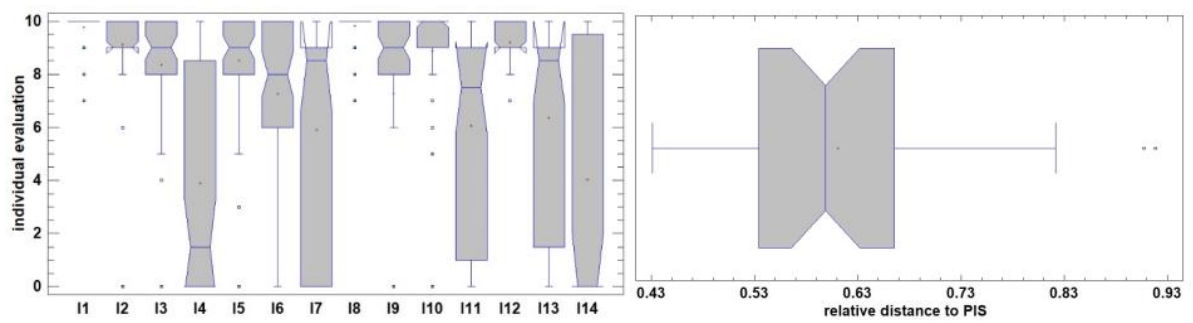

Source: own processing.

A very high level of the online information being disclosed was detected for 4 (8\%) of retirement homes. A lesser than the very high level of the online information being disclosed was detected for $22(42 \%)$ of retirement homes. A low level of the online information being disclosed was detected for $26(50 \%)$ of retirement homes. A very low level of the online information being disclosed was not detected within this type.

Results for the type B retirement homes: retirement homes with the legal form of Ltd companies

The evaluation of the online information I1 - I14 being disclosed for the type B retirement homes is strongly heterogenous (Fig. 2). Based on the performed analysis of the range of individual 14 types of information under conditions of 52 type B retirement homes, it can be stated that one very strong information gap was detected, which was the gap related to:

- $\quad$ I7 annual reports of the retirement home,

and three strong information gaps were detected, and these were the gaps related to:

- I4 criteria for the acceptance into the retirement home,

- $\quad$ I13 internal rules of the home and

- $\quad$ I14 electronic link for the communication with the retirement home.

Figure 2. Type $B$ retirement homes: the range of the criteria and the $c_{i}$ values
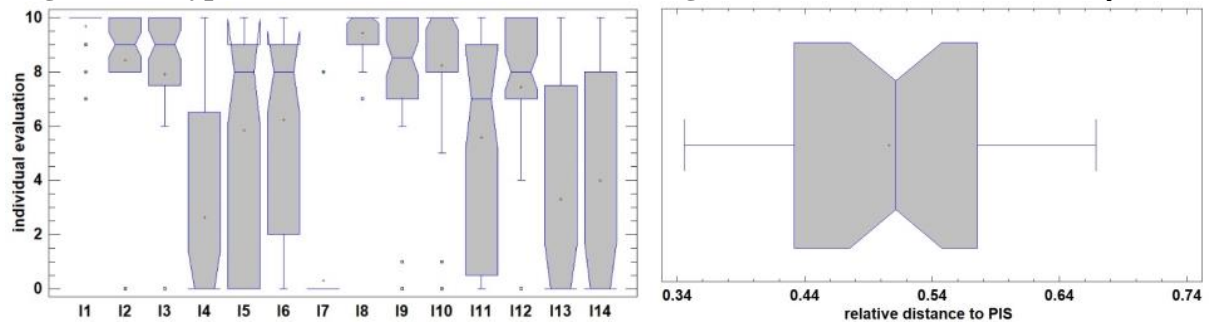

Source: own processing.

While evaluating the accessibility of the studied types of information within the type $\mathrm{B}$ retirement homes, relatively higher differences can be observed in the evaluation of individual social facilities or their websites $(R=0.323$; $v=18.13 \%)$. Despite minimal differences in the mean values of the $c_{i}$, it can be stated that there is negative skewness of the results, absence of distant or extreme observations, and the hypothesis on 
normal distribution is rejected $(\mathrm{w}=0.948 ; \mathrm{p}=0.041)$. The mean value of the $c_{i}$ is 0.51 ; the minimum value of the $c_{i}$ is 0.35 ; and the maximal value of the $c_{i}$ is 0.67 .

A very high level of the online information being disclosed was not detected. A lesser than the very high level of the online information being disclosed was detected for 8 $(15 \%)$ of retirement homes. A low level of the online information being disclosed was detected for $38(73 \%)$ of retirement homes. A very low level of the online information being disclosed was detected for $6(12 \%)$ of retirement homes.

Results for the type $C$ retirement homes: retirement homes with the legal form of church non-profit organizations

The evaluation of the accessibility of the types of information (I1 - I14) being disclosed by the type $\mathrm{C}$ retirement homes is strongly heterogenous (Fig. 3).

Based on the performed analysis of the range of individual 14 types of information under conditions of 55 type $\mathrm{C}$ retirement homes, it can be stated that four considerable information gaps were detected, and these gaps were detected for:

- I4 criteria for the acceptance into the retirement home,

- I9 localization contact information of the retirement home,

- I11 activities in the retirement home,

- I13 internal rules of the home.

The total results of the studied group of the type $\mathrm{C}$ retirement homes show positive skewness, the majority of websites were evaluated as below-average (Fig. 3). A higher variability $(\mathrm{v}=24.67 \%)$ is caused by small groups of entities that took places at both sides of the evaluation spectrum, which was shown in the higher inter-quartile range $(\mathrm{IQR}=0.177)$ and negative kurtosis $(\gamma=-0.625)$. The quality of the information available, expressed via the standard deviation or the variation coefficient, is the most heterogenous in the case of evaluation of the determined set of indicators. The mean value of $c_{i}$ is 0.47 ; the minimal value of $c_{i}$ is 0.28 ; and the maximal value of $c_{i}$ is 0.74 .

Figure 3. Type $\mathrm{C}$ retirement homes: the range of the criteria and the $c_{i}$ values

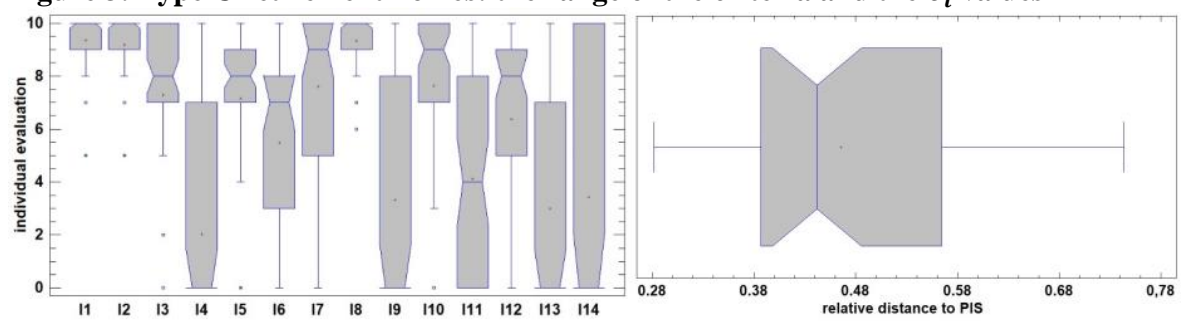

Source: own processing.

A very high level of the online information being disclosed was not detected. A lesser than the very high level of the online information being disclosed was detected for 6 $(10 \%)$ of retirement homes. A low level of the online information being disclosed was detected for $30(55 \%)$ of retirement homes. And finally, a very low level of the online information being disclosed was detected for 19 (35\%) of the type C retirement homes. 


\section{Complex results for all types $(A, B, C)$ of retirement homes}

The results of the $c_{i}$ for 159 entities (websites of all type $\mathrm{A}, \mathrm{B}$, and $\mathrm{C}$ retirement homes) studied as the results of one group showed lower mean value and corroborated the hypothesis on normal distribution of results $(\mathrm{w}=0.971 ; \mathrm{p}=0.066)$. Two entities do not follow the overall structure of results in a positive way; these entities reached higher than 0.9 value of the relative distance to the PIS for all the indicators (I1-I14).

In general, the best results were achieved by the type A retirement homes, and also the two abovementioned entities with the best rating among all 159 entities belong to type A. The single-factor analysis of variance corroborated the assumption on differences between individual types of retirement homes, and it also identified these differences as statistically significant $(\mathrm{F}=17.61 ; \mathrm{p}<0.01)$.

Putting all three types (A, B and C) together did not affect the results' structure, which was corroborated by the comparison of the mean value of the $c_{i}$ reached within a set of entities of a certain type of retirement homes with the value reached within the whole set of 159 entities, (Tab. 2).

Table 2. Comparison of the mean $c_{i}$ values

\begin{tabular}{lccr}
\hline & retirement home & within the type & within all types \\
\hline \multirow{3}{*}{ mean $c_{i}$} & Type A & 0.6110 & 0.6144 \\
& Type B & 0.5061 & 0.5359 \\
& Type C & 0.4655 & 0.4931 \\
\hline \multirow{3}{*}{ median $c_{i}$} & Type A & 0.5988 & 0.6049 \\
& Type B & 0.5116 & 0.5353 \\
& Type C & 0.4420 & 0.4639 \\
\hline
\end{tabular}

Source: own calculation.

The total level of the information being disclosed is evaluated according to the determined four-level scale for the $c_{i}$ values, where from the perspective of 159 evaluated entities (Fig. 4):

- a very high level of the information being disclosed, when the value of the relative closeness to the PIS $\left(c_{i}\right)$ lies within the interval [1.00-0.80], was achieved by $3 \%$ of the studied entities; this level was only reached by four type A entities;

- a lesser than the very high level of the information being disclosed, when the $c_{i}$ the value lies within the interval $[0.79-0.60]$, was reached by $30 \%$ of the studied entities; the majority of entities on this level were the type A entities;

- a low level of the information being disclosed, when the $c_{i}$ the value lies within the interval [0.59-0.40], was reached by $60 \%$ of the studied entities; the majority of entities on this level were the type B entities;

- a very low level of the information being disclosed, when the $c_{i}$ the value lies within the interval $[0.39-0.10]$, was reached by $7 \%$ of the studied entities; the majority of entities on this level of the information being disclosed were the type $\mathrm{C}$ entities. 
Figure 4. The level of online information being disclosed by the researched retirement homes

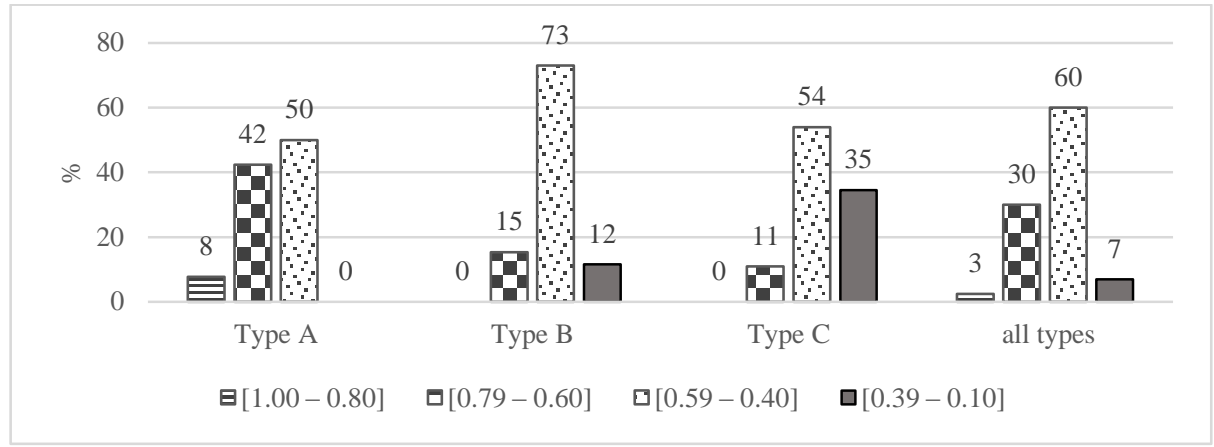

Source: own processing.

\section{Discussion}

The information about the supply of social services available can currently be gained in several ways (personal and remote types of access). This fact follows a legislative requirement effective for every provider of social services, regardless of the type of service being provided. The accessibility of information about social services can be expressed as an indicator of reachability of the social service for potential clients.

Nowadays, the websites represent the most used mean of communication with the potential clients of social services as well as with the public. Thus, it is legitimate to expect that social services in the form of retirement homes should be maximally transparent regarding their specific societal nature as well as their relatively high proportion of funding from the public budgets.

The results of the multi-criteria and statistical analyses show that (see research questions RQ1, RQ3) all the evaluated retirement homes offer almost full information on the type of social service provided, and they also state its description. Nevertheless, within the area of basic and practical information, an unexpected considerable information gap was detected, especially in the case of type B and type $\mathrm{C}$ retirement homes, in the form of information (I4) about the conditions for the acceptance into the retirement home, thus the piece of information about how the individual applications for acceptance will be assessed. At the same time, especially from the side of providers of retirement homes (type B), the currently valid price lists for the services being provided are not being sufficiently disclosed, and the disclosure of annual reports is almost non-existent. The information gaps of the evaluated retirement homes also include the information within the area of contact and additional information, especially the piece of information about organizational and technical conditions and the rules in the form of a list of home's internal rules (I13) are missing, together with the electronic link for the communication with the retirement home (I14). The absence of these types of information considerably limits the decision-making ability of potential clients, which results in the emergence of additional costs (time and financial) needed for the additional searching for them. Pertaining to this, the results gained can be confronted with the opinion that the provided online information about social services of retirement 
homes needs to be seen as a product that has its current and future value, for the concrete client as well as for the public, (Holasová Malík, 2014, Prǔša, 2013).

The partial as well as the complex evaluation of the level of information being provided by retirement homes, according to the TOPSIS technique, detected considerable differences among individual types of the legal form of retirement homes (see research question RQ2). A low level of information being disclosed is provided by $60 \%$ of researched retirement homes, and the majority of retirement homes on this level are the retirement homes with the legal form of Ltd companies (type B). A very low level of the information being disclosed is provided by $7 \%$ of retirement homes, and the majority of retirement homes on this level of information being provided are the retirement homes with the legal form of church organizations (type C).

The level of online information being provided by retirement homes operated by private entities of commercial or church nature is very low. The remaining question is "why"? There is an assumption stated by Janíčko and Koubek (2012) that the persons interested in social service, when making a decision based on the information available, can tend to choose the provider of social services who seems to be the best one and who is able to sufficiently satisfy their needs. Moreover, private providers of retirement homes must face economic superiority as well as the superiority in numbers of public providers in the form of state-funded organizations of regions and municipalities. There are several possible answers to the above-stated question. Nevertheless, the official statistics and studies available (Czech Statistical Office, 2017; Prǔša and Horecký 2012; Průša, 2013; Association of Social Services Providers of the Czech Republic, 2010) show that there is an excess of demand over supply in the market of residential social services for the retired people in the Czech Republic, which is not directly caused by the decrease of the service's price but by other socio-economic, demographic and political factors. Therefore, at least it can be assumed that the providers are not sufficiently economically motivated to provide the information on a high level.

The results for the type A retirement homes (semi-budgetary units of regions) can be seen as very critical, where only $8 \%$ of these retirement homes disclose the information on a high level, $42 \%$ provide lesser than high level of the information, and 50\% of these homes provide only a low level of the information being disclosed. Therefore, it can be stated that the retirement homes with the legal form of semi-budgetary units of regions do not represent a security and an example of fully accessible online information within this area of social services.

\section{Conclusion}

The information gaps within the area of supply of social services of 159 selected retirement homes related to the online information being disclosed during January and February 2019 were researched based on the assumption of occurrence of information asymmetry and its negative impact on the decision-making of the clients, as well as on the quality of the social services being provided.

The researched set of 159 official websites of retirement homes consisted of 52 websites of retirement homes that are established by self-governing regions as semi- 
budgetary units of regions, 52 websites of retirement homes that are established by private entities as Ltd companies, and 55 websites of retirement homes that are established by churches as church legal entities.

Within the identification and evaluation of the information gaps, 14 types of information were tested, consisting of two sets: (1) basic and practical pieces of information, and (2) contact and additional pieces of information. The information gaps were analysed according to the multi-criteria TOPSIS method for the evaluation of different variants.

Within the solving, three research questions were tested. The first research question was focused on the level of basic and practical pieces of information being provided. Within this set of information types, a significant information gap was identified in the form of the piece of information about the conditions for the acceptance into a retirement home, which occurred by all three types of retirement homes, especially by those that are established by private entities and church organizations.

The second research question was focused on the differences in the quality of online information being provided by the retirement homes with regard to the type of provider. On average, the best online information for the clients and for the public on the services provided are given by the retirement homes of public establishers (regions). Nevertheless, within the websites of this type of retirement homes, a lesser than high level of the information being provided was detected by $42 \%$ of websites, and a low level was detected by $50 \%$ of these retirement homes. The websites of private and church retirement homes provide information with a low and very low level $(85 \%$ of the Ltd companies and $89 \%$ of church legal entities).

Besides the abovementioned information gap, other gaps were identified too, and these were within the context of testing of the third research question. It is mostly the case of additional contact information that helps localize (find) the seat of the retirement home in the map/area and facilitate the search for the transport connection ("How will you get to us?"). Websites of retirement homes also insufficiently inform on the leisure time activities and possibilities in the retirement homes, on the internal rules effective in the building and other spaces of the retirement home, and they do not offer an electronic link for the communication with the retirement home.

Respecting the methodological and time limit, the results gained in the form of specific information gaps of retirement homes' websites show a problem that is directly linked to the quality of the social services being provided and indirectly linked to the organization and funding of social services established for the retired people in the Czech Republic.

Funding: This paper was supported by the project SGS No. SP2019/10, Impact of Socio-economic Factors on Availability of Selected Social Services in the Czech Republic, Faculty of Economics. VŠB - Technical University of Ostrava and was supported within the Operational Programme Education for Competitiveness - Project No. CZ.1.07/2.3.00/20.0296.

Disclosure statement: No potential conflict of interest was reported by the authors. 


\section{References}

ARDIELLI, E., BEČICA, J. (2018). Multi-criteria Evaluation of the State of Professional Theatres in the Czech Republic in Terms of Mixed Public Goods Provided to the Citizens. Review of economic Perspectives, 18 (2), 156-176. DOI:10.2478/revecp-2018-0009

ARROW, K. J. (1963). Uncertainty and the Welfare Economics of Medical Care. The American Economic Review, 53 (5), 941-973.

Association of Social Services Providers of the Czech Republic. (2010). Komparace služeb sociální péče o seniory. Tábor: Association of Social Services Providers of the Czech Republic. [online]. Retrieved January 21, 2018, from http://www.apsscr.cz/files/projekty/island_komparace.pdf

BARILE, S., SAVIANO, M. \& POLESE, F. (2014). Information asymmetry and cocreation in health care service. Australasian Marketing Journal, 22 (3), 205-217. DOI: 10.1016/j.ausmj.2014.08.008

BLOOM, G., STANDING, H. \& LLOYD, R. (2008). Markets, information asymmetry and health care: towards new social contracts. Social Science \& Medicine, 66(10), 2076-2087. DOI: 10.1016/j.socscimed.2008.01.034

BOYER, M., MAHENC, P., MOREAUX, M. (2003). A symmetric information and product differentiation. Regional Science and Urban Economics. 33(1), 93-113. DOI: 10.1016/S0166-0462(01)00108-9

Czech Statistical Office. (2017). Senioři v mezinárodním srovnání 2017. [online]. Retrieved March 6, 2019, from https://www.czso.cz/csu/czso/seniori-v-cr-v-datech2017

Czech Social Security Administration. (2018). Důchodová statistika. [online]. Retrieved March 6, 2019, from https://www.cssz.cz/web/cz/duchodovastatistika\#section_0

FRANK, R.G., SALKEVER, D. S. (1994). Nonprofit Organizations in the Health Sector. Journal of Economics Perspectives, 8(4), 129-144. DOI: 10.1257/jep.8.4.129

HAAS-WILSON, D. (2001). Arrow and the Information Market Failure in Health Care: The Changing Content and Sources of Health Care Information. Journal of Health Politics, Policy and Law, 26(5), 1031-1044. DOI: 10.1215/03616878-26-51031

HOLASOVÁ MALÍK, V. (2014). Kvalita v sociální práci a sociálních službách. Praha: Grada Publishing, a. s.

HUANG, C., KU, Y. (2011). Effectiveness of Social Welfare Programmes in East Asia: A Case Study of Taiwan. Social Policy \& Administration, 45(7), 733-751. DOI: 10.1111/j.1467-9515.2011.00794.x

JABLONSKÝ, J., DLOUHÝ, M. (2015). Modely hodnocení efektivnosti a alokace zdroju․ Praha: Professional Publishing. 
JANÍČKO, M, KOUBEK, I. (2012). Informační asymetrie a systém dvojího standardu ve vztahu zdravotník-pacient. Politická ekonomie, 60 (3), 362-379. DOI: 10.18267/j.polek.854

JUREČKA, V. a kol. (2018). Mikroekonomie. Praha: Grada Publishing, a. s.

KERŠUIENE, V., ZAVADSKAS, E. K., TURSKIS, Z. (2010). Selection of rational dispute resolution method by applying new step-wise weight assessment ratio analysis (Swara), Journal of Business Economics and Management. 11, 1611-1699, DOI: 10.3846/jbem.2010.12

KUBALČÍKOVÁ, K., HAVlÍKOVÁ, J. (2016). Current Developments in Social Care Services for Older Adults in the Czech Republic: Trends Towards Deinstitutionalization and Marketization. Journal of Social Service Research. 42(2), pp. 180-198. DOI: $\underline{10.1080 / 01488376.2015 .1129014}$

McCAUGHEY, D., BRUNING, N, S. (2010). Rationality versus reality: the challenges of evidence-based decision making for health policy makers. Implementation Science, 5 (39), 1-13. DOI: 10.1186/1748-5908-5-39

MERTL, J. (2008). Přistupy k hodnoceni efektivnosti sociálních služeb v národním hospodářství. Praha: Výzkumný ústav práce a sociálních věcí.

Ministry of Labour and Social Affairs of the Czech Republic. (2019). Registr poskytovatelů sociálních služeb. [Register of Social Service Providers]. Prague: Ministry of Labour and Social Affairs. http://iregistr.mpsv.cz/socreg/vitejte.fw.do;jsessionid=7795B270B4189FB75A3035C EC13DB7E2.node1?SUBSESSION_ID=1555242256564_1

NETTEN, A., DAVIES, B. (1990). The Social Production of Welfare and Consumption of Social Services. Journal of Public Policy, 10(3), 331-347. DOI: $\underline{10.1017 / \mathrm{S} 0143814 \mathrm{X} 00005857}$

OLSON, D. L. (2004). Comparison of Weights in TOPSIS Models. Mathematical and Computer Modelling, 40(7-8), 721-727. DOI: 10.1016/j.mcm.2004.10.003

PRŮŠA, L. (2007). Ekonomie sociálnich služeb. Praha: ASPI, a. s.

PRŮŠA, L., HORECKÝ, J. (2012). Poskytování služeb sociální péče pro seniory v České republice a ve Švýcarsku: mezinárodní komparace. Tábor: Association of Social Services Providers of the Czech Republic. [online]. Retrieved Februrary 2, 2019, from http://www.horecky.cz/images/1345613843_komparace-c-s.pdf

PRŮŠA, L. (2013). Ekonomická efektivity zajištování péče o př́jemce př́spěvku na péči. Praha: Výzkumný ústav práce a sociálních věcí.

ROBINSON, J. C. C. (2001). The End of Asymmetric Information. Journal of Health Politics, Policy and Law 26(5), 1045-1053. DOI: 10.1215/03616878-26-5-1045

ROBLIN, B., DEBER, R., KULUSKI, K., SILVER, M. P. (2019) Ontario's Retirement Homes and Long-Term Care Homes: A Comparison of Care Services and Funding Regimes. Canadian Journal on Aging. Article in Press. DOI: $\underline{10.1017 / \text { S0714980818000569 }}$ 
SEIFERT, A., SCHELLING, H. R. (2018). Attitudes Toward Aging and Retirement Homes Before and After Entry Into a Retirement Home. Journal of Housing for the Elderly. 32 (1) p. 12-25. DOI: 10.1080/02763893.2017.1393484

SCHAAD, M. (1998). Neziskové organizace v ekonomické teorii. Brno: Masarykova univerzita.

SOJKA, M. (2002). Asymetrické informace a jejich důsledky pro metodologii ekonomie. Ekonomika, právo a politika, CEP: Sborník č. 19 "Investiční pobídky". [online]. $\quad$ Retrieved $\quad$ Februrary 11, 2019, from http://www.cepin.cz/cze/kniha.php?ID=23

STREIMIKIENE, D., BALEZENTIS, T., KRISCIUKAITIENE, I., BALEZENTIS, A. (2012). Prioritizing sustainable electricity production technologies: MCDM approach, Renewable \& Sustainable Energy Reviews. 16(5), 3302-3311. DOI: 10.1016/j.rser.2012.02.067

VARIAN, H. R. (2014). Intermediate Microeconomics. New York: W.W. Norton \& Company.

VAVREK, R. KOTULIČ, R., ADAMIŠIN, P. (2015). Evaluation of municipalities management with the topsis technique emphasising on the impact of weights of established criteria. Lex localis - Journal of Local Self-Government. 13(2) 249-264, DOI: 10.4335/249-264(2015)

VLACHANTONI, A. (2019). Unmet need for social care among older people. Ageing and Society. 39 (4), 657-684. DOI: 10.1017/S0144686X17001118

ZAVADSKAS, E. K., TURSKIS, Z., KILDIENE, S. (2014). State of art surveys of overviews on MCDM/MADM methods, Technological and Economic Development of Economy. 20(1), 165-179. DOI: 10.3846/20294913.2014.892037

ZAVADSKAS, E. K., MARDANI, A., TURSKIS, Z., JUSOH, A., NOR, K. (2016). Development of TOPSIS Method to Solve Complicated Decision-Making Problems: An Overview on Developments. From 2000 to 2015, International Journal of Information Technology \& Decision Making. 15 1-38, DOI: 10.1142/S0219622016300019. 